Article

\title{
Impact of Advanced Manufacturing Technologies on Green Innovation
}

\author{
Iztok Palčič ${ }^{1, *(\mathbb{D})}$ and Jasna Prester ${ }^{2}$ (D) \\ 1 Faculty of Mechanical Engineering, University of Maribor, Smetanova ulica 17, 2000 Maribor, Slovenia \\ 2 Faculty of Economics \& Business, University of Zagreb, Trg J. F. Kennedyja 6, 10000 Zagreb, Croatia; \\ jprester@efzg.hr \\ * Correspondence: iztok.palcic@um.si
}

Received: 26 March 2020; Accepted: 20 April 2020; Published: 24 April 2020

\begin{abstract}
The main aim of this paper is to evaluate if manufacturing firms can boost their performance through green innovations. The literature on this topic shows contradictory findings. We have concentrated on the effect of advanced manufacturing technologies (AMT) on green innovations. To the authors' best knowledge, this research is the first to examine the impact of a firm's own AMT on green innovation and the firm's performance at the same time. Green innovation in our research relates to green product innovation. The data analysis is performed through three-step OLS regression analysis and two evaluation models. One model looks at AMT and how they affect green innovation, and the second model looks at how AMT and green innovations affect performance. Our findings suggest that AMT contribute to both the firm's performance and green innovation. We found that technology is a moderator for green innovations. While the majority of research emphasizes that firms will not eco-innovate unless they receive subsidies or severe restrictions are imposed, we show that out of all innovations, $66 \%$ are green innovations. Restrictions such as having ISO 14000 certification do not contribute to green innovation, but rather the age of the firm does.
\end{abstract}

Keywords: green innovation; advanced manufacturing technology; European manufacturing survey; firm performance

\section{Introduction}

The manufacturing sector in Europe contributes more than $26 \%$ of the value-added share in non-financial business [1]. Manufacturing is confronted with several megatrends and significant innovations worldwide and has to constantly innovate in order to stay competitive. Manufacturing has a prevalent role in modern society in terms of societal service and in contributing towards the regional, national and global economy [2]. At the same time, Industry 4.0 smart production systems require innovative solutions to improve the quality and sustainability of the manufacturing industry. Therefore, advanced manufacturing technologies (AMT) must assist with these goals [3].

Research on environment issues continues to receive massive attention from practitioners and academia. However, there is limited evidence that firms are able to obtain above average business results through green innovation, or for that matter, outperform their competitors [4-6]. Besides that, the literature on this topic shows contradictory findings [7-10]. The main aim of this research is to find out if firms are able to boost their performance through environmentally sound new products. Of course, a boost in performance would be a combination of many factors [8], but according to [7], green innovations have an impact on firms' competitive advantage and their image. Lin et al. [9] and Chan et al. [8] have shown that green innovations have a positive effect on firm performance. On the contrary, Tang et al. [10] show that process innovation, that is, technology, leads to higher performance, but green innovations do not. This is another reason to include technology or process innovations in 
this research. From the perspective of the authors of [10], green innovation's results and effects on performance are still inconclusive. Xie et al. [11] also find the relationship inconclusive. El-Kassar and Singh [12] do not find a positive effect of green innovations on performance, but do find a positive effect of green process innovations on a firm's performance. Przychodzen and Przychodzen [13] and Grewatsch and Kleindienst [14] also show mixed results. This means that most AMT tend to improve efficiency and save space, capital and human resources, resulting in greener processes that consume less energy.

Green innovation encompasses product and process innovation, and it means improvements in product design and manufacturing processes. Green process innovations include the introduction of technologies that can save energy, minimize waste, reduce pollution, and decrease a firm's negative impact on the environment [15-20]. Green innovations are usually created through the usage of more environmentally friendly materials or the reduction of negative environmental impacts during a product's life cycle [8]. Guoyou et al. [21] define green innovation as "an instrument to improve firms' environmental management process", and it is related to any changes, either technological, organizational, societal, or institutional, that result in a reduction of environmental burdens.

As already mentioned, performance depends on many factors. In this work, we have concentrated only on the effect of AMT on environmentally sound products. Ghobakhloo and Azar [22], for example, list many benefits of AMT, and suggest that AMT are able to speed up new product development. Therefore, there is evidence in the literature that environmentally sound new products can boost performance and that AMT can be amongst the many factors that make innovation successful. AMT are a firm's resources, and according to Tse et al. [23] and Wu et al. [24], they should be better allocated. One of the resources in a manufacturing firm is certainly the manufacturing technology.

Therefore, this paper contributes to the new product development research by analyzing the relationship between AMT and green innovation. This research contributes to theory in trying to improve our understanding of the relationship between green innovation performance and a firm's financial performance and summarize different findings about the link between green innovation performance and a firm's financial performance.

The analysis is performed using European Manufacturing Survey project [25] data from two southern European countries, namely Slovenia and Croatia, comprising more than 200 manufacturing plants. The analysis is performed through three-step OLS regression analysis and two evaluation models. One model looks at technologies and how they affect green innovation, and the second model looks at how technology and green innovations affect performance.

The remainder of this paper is organized as follows: Section 2 gives an overview of the relevant literature on AMT and green innovation, and presents the hypothesis development. In Section 3 , we describe our data and research methodology. Section 4 presents our results with a short overview of the frequency of AMT use. In Section 5, research results are discussed and analyzed. Finally, the limitations and directions for future research are specified in Section 6.

\section{Theoretical Background}

\subsection{Advanced Manufacturing Technology}

According to Kusiak [26], there is no generally accepted definition of advanced manufacturing, and he cites the National Institute of Standards and Technology, who state that advanced manufacturing is: "[a] fully integrated, collaborative manufacturing system that responds in real time to meet changing demands and conditions in the factory, in the supply network and in customer needs. Advanced manufacturing integrates manufacturing activities with sensors, computing platforms, communication technology, data modelling, simulation and predictive engineering."

According to Mittal et al. [27], advanced manufacturing is technology that can integrate production systems such as "flexible manufacturing system (FMS), reconfigurable manufacturing system (RMS), computer integrated manufacturing (CAM) and additive manufacturing, (sensing) technology, which 
can help monitor tracking and tracing, and these sensors are referred to as smart sensors." They also list the use of anti-metallic radio-frequency identification (RFID) in manufacturing environments, enterprise resource planning (ERP), supply chain management (SCM), and manufacturing execution systems (MESs), as well as product lifecycle management (PLM). RFID tags are used for tracking materials and tools; ERP is the brain of the enterprise and connects different parts of the enterprise, such as connecting inventory management and production with financial reporting, marketing and payroll, etc. Supply chain management builds on ERP systems and connects the manufacturing firm with its suppliers and customers. Manufacturing execution systems (MESs) enable IT monitoring and management of the transformation of materials into products. Product lifecycle management (PLM) is managing and surveying the product throughout its whole lifecycle.

\subsection{Green Innovations}

According to Cainelli et al. [28], a broad picture of the innovative potential in the field of green innovation and technologies is still lacking. They find that product-related eco-innovations are strongly affected by policy. García-Quevedo et al. [29] link eco-innovation with the adoption of the ISO 14000 environmental standard, similar to in [28]. Arranz et al. [30] conclude that the density of firms in the region, the regional per capita income, and the existence of financing mechanisms are key elements for the eco-innovative development in the firm. Prokop et al. [31], on the other hand, propose that it is the market that demands eco-innovations. Łaszkiewicz [32] emphasizes the balance between tendencies of firms related to responsibility and, on the other hand, the firm's leading goal to maximize profits and build a competitive advantage on the market, which is often perceived as acting in contradiction with sustainable management. Common points of both these areas, which are in some contradiction, are green innovations or broadly understood innovations supporting sustainable development. Arranz et al. [33] show a negative decision to eco-innovate in Spain, unless the government helps with incentives. Colombelli et al. [34] claim that stringent regulation influences the demand for eco-innovations. They prove it by showing that eco-regulation is a negative moderator for business growth. Through this brief literature review of the most recent articles on eco-innovation, it can be concluded that firms are motivated by regulations and they eco-innovate to stay within the regulatory boundaries. Only Łaszkiewicz [32] states that firms eco-innovate for corporate image, but with a huge balance between costs and benefits.

\subsection{Hypothesis Development}

The literature has shown that better management of a firm's internal resources can lead to green innovation, and thus to improved financial performance [35]. Used properly, internal resources can lead to better firm environmental impact [36]. Internal resources, apart from human resources, also include manufacturing technologies. To the authors' best knowledge, this research is the first to examine the impact of a firm's internal technological resources (AMT) on green innovation, as well as the link between AMT, green innovation and firm financial performance. The literature on green innovation has increased over the past few decades [37] but there are still contradictory findings. According to [38], green innovations and compliancy with all environmental concerns can form a differentiation from rivals.

It is hypothesized that a firm that has adopted certain AMT before its competitors will have at least a temporary competitive advantage. Adoption of new AMT will enable faster launch of new products (innovation), and thus also green innovations. Consequently, the first hypothesis is that AMT will enhance the introduction of new green innovation in terms of green products:

Hypothesis 1 (H1). AMT positively relate to the introduction of new green innovation, moderated by innovation. 
Since the literature suggests that green innovations are, except in very rare cases, a result of brand image rather than environmental regulation policies, we have to test if firms who have adopted the ISO 14000 certificate produce more eco-environmental products.

Hypothesis 2 (H2). Adoption of the ISO 14000 certificate positively influences green innovations.

Ghobakhloo and Azar [22] in their work list all the AMT, but in their model, technologies are represented by a single latent variable. In our case, we preferred to keep the full list of AMT to see each technology's contribution to green innovation performance. Information technology is advancing so fast that manufacturing firms launch new products in shorter and shorter cycles. However, this means a great amount of pressure on every manufacturing firm because they have to stay in line with their competitors. In addition, constant changes in customer preferences impose additional pressure on manufacturing firms. Consequently, firms are rushing to implement operational programs and best practices that have been successful in other firms [39]. Manufacturing firms are continuously trying to strengthen their competitive position by implementing AMT faster than their competitors [40]. Case studies have shown that AMT positively affect tangible (such as cost, inventory, etc.) and intangible (such as product quality, flexibility, etc.) resources of the firm. However, the use of advancement in technology requires constant modification in the existing manufacturing system and its everyday practices [41]. AMT coupled with changes in the organizational and human behavior [42] can additionally strengthen competitive position. Therefore, the third hypothesis is that AMT will positively affect return-on-sales (ROS) through innovations.

Hypothesis 3 (H3). AMT will positively relate to ROS, moderated by innovation.

\section{Research Methodology}

\subsection{Data Collection}

The research data were collected through the European Manufacturing Survey (EMS), the largest European manufacturing survey [43]. The main objective of the EMS project is to track production practices in European manufacturing firms. The survey includes questions about production and information technologies, new organizational concepts and the implementation of modern manufacturing/management practices [44]. The questions in the survey cover manufacturing strategies, technological concepts in production and servitization, and data on performance indicators such as productivity, flexibility, quality and sales. The survey is conducted among manufacturing firms (NACE Rev. 2, codes 10 to 32) with at least 20 employees on a three-year basis. Currently, the dominant research streams using EMS data are in the areas of servitization, energy efficiency and relocation [45]. There are other publications that use the same methodology in the field of servitization [46-49], in the field of energy efficiency [50,51], and in the field of relocation [52]. To collect valid data permitting international comparisons, the EMS consortium employs various procedures recommended by the Survey Research Centre. In line with this, the items and scales used as measurement instruments in the EMS study were developed from an extensive review of the current literature on manufacturing practices. To ensure the validity of the content, a literature review was performed and the draft questionnaire reviewed by a panel of experts before being piloted in several plants [53]. It was also subject to analysis for reliability and construct validity through the usual statistical methods (inter-correlation matrixes, Cronbach's alpha [54], factor analysis and canonical correlation, among others).

The Croatian and Slovenian sub-samples are used for the purpose of the present research, mainly because these are two neighboring countries and are not as developed as leading European economies such as Germany or France. The questionnaires were sent to chief executive officers of manufacturing firms in March 2018. The data collected cover 105 usable responses from Croatia and 127 from Slovenian compiled in the 2019 edition of the EMS database for this analysis. 


\subsection{The Sample}

Our sample constitutes 232 firms, of which $33.6 \%$ of firms are small (number of employees up to 50 ), $43.1 \%$ are medium-sized (from 50 to 250 employees), and $23 \%$ are large firms (more than 250 employees). We identified three types of products in terms of complexity, where the firms themselves provided the assessment of the product complexity: simple products (less components, different materials, conventional technologies), medium-complexity products (e.g., pumps, a large number of parts and technologies used, easy assembly), and complex products (e.g., machines, a large number of components, materials, and technologies used, demanding assembly). Simple products are produced by $18.1 \%$ of firms, $48.3 \%$ of firms produce products of medium complexity, while $31.5 \%$ of firms produce complex products, as seen in Table 1. In our case, complexity refers to the main product. If a firm produces several products of varying complexity, the complexity refers to the product that brings the firm the most revenue. Complexity is an important contextual factor as shown by Sousa and Voss [55]. It is therefore an obvious choice to include it as a control variable.

Table 1. Descriptive statistics of the sample by firm size and complexity of the manufactured products.

\begin{tabular}{ccc}
\hline Firm size & Frequency & Percent \\
\hline Small ( $<50$ employees $)$ & 78 & 33.6 \\
\hline Medium (50-249 employees) & 100 & 43.1 \\
\hline Large ( $>250$ employees) & 54 & 23.3 \\
\hline Total & 232 & 100 \\
\hline Product complexity & Frequency & Percent \\
\hline Simple products & 42 & 18.1 \\
\hline Medium-complexity products & 112 & 48.3 \\
\hline Complex products & 73 & 31.4 \\
\hline No data & 5 & 2.2 \\
\hline Total & 232 & 100 \\
\hline
\end{tabular}

Since $\mathrm{Yu}$ et al. [56] and Bahemia and Squire $[57,58]$ argue that innovation performance can be quite different depending on the product complexity, we included complexity as a control variable. A reason to include it as a control variable is found in the works of $[57,58]$, where they state that product complexity is a contingence factor. We have tested the moderating effect of product complexity on ROS and green innovation to seek comparability with Martinsuo and Poskela [59], who tested the role of product complexity as a possible moderator between the evaluation and success of a new product, but did not find any moderation effect.

In our research, innovators were firms that introduced a new product within the last 3 years. These products can be either new for their firm or incorporating major technical improvements-products new for the market. Additionally, we asked the firms whether these new or improved products also lead to an improved environmental impact when using or disposing of them in terms of reduced health risks during use, reduced energy consumption during use, reduced environmental pollution during use, improved recycling, take-back or disposal properties, etc. Table 2 presents the share of firms that introduced new products (innovation: major technical improvement) and the share of firms with new products that also lead to improved environmental impact (green innovation: improved environmental impact). The shares are calculated for four groups of firms according to technological intensity and based on NACE Rev. 2. Furthermore, we also included ROS as a measure of firm financial performance, a ratio widely used to evaluate a firm's financial (business) efficiency [49]. In our case, ROS was a quantitative variable constructed from the range of ROS with values: 0 for ROS $<0 \%, 1$ for ROS $0 \%-2 \%$, 2 for ROS $>2 \%-5 \%, 3$ for ROS $5 \%-10 \%$, and 4 for ROS $>10 \%$. 
Table 2. Descriptive statistics of the sample by NACE, number of firms introducing new products, and return-on-sales (ROS).

\begin{tabular}{cccc}
\hline $\begin{array}{c}\text { Technological Intensity of } \\
\text { the Industry Group }\end{array}$ & $\begin{array}{c}\text { Innovation: Major } \\
\text { Technical Improvement }\end{array}$ & $\begin{array}{c}\text { Green Innovation: Improved } \\
\text { Environmental Impact }\end{array}$ & $\begin{array}{c}\text { Average } \\
\text { ROS }\end{array}$ \\
\hline Low technology & $69 \%$ & $46 \%$ & 3.18 \\
\hline Medium-low technology & $69 \%$ & $44 \%$ & 3.40 \\
\hline Medium-high technology & $74 \%$ & $54 \%$ & 3.18 \\
\hline High technology & $78 \%$ & $44 \%$ & 3.67 \\
\hline Average & $72 \%$ & $47 \%$ & 3.36 \\
\hline
\end{tabular}

As can be seen from Table 2, even low-technology industries such as food, textiles and wood innovate (there are 25 green innovations in the low-technology sector, or $46 \%$ of the total sample of low-tech industry). The share of innovations grows with increasing industry technological intensity. It is not the same for the growth of green innovators: there is only a $44 \%$ share of green innovators in high-technology industries, whereas in medium-high-technology industries this share is $54 \%$. Altogether, out of 162 innovators, 107 innovations are green innovations, meaning a 66\% share. As far as ROS is concerned, high-technology industries are the most profitable (average ROS 3.67). Overall ROS average is also high (3.36), which falls into the category of ROS in the range from $5 \%$ to $10 \%$.

\section{Results}

One aim was to prove the hypothesis that AMT positively affect green innovation and ROS. We can see in Table 3 that our dependent variables are highly correlated. Innovations significantly positively influence ROS $\left(0.215^{* * *}\right)$ as well as green innovations $\left(0.472^{* * *}\right)$. However, from Table 3 it can also be seen that green innovations do not impact ROS. The correlation coefficient is negligible and not significant $(0.021, p>0.05)$.

Table 3. Correlations between dependent variables.

\begin{tabular}{cccc}
\hline Correlation table & ROS & Innovation & Green innovation \\
\hline ROS & 1 & & \\
\hline Innovation & $0.215^{* * *}$ & 1 & 1 \\
\hline Green innovation & $0.021(0.76)$ & $0.472^{* * *}$ & \\
\hline \multicolumn{4}{c}{${ }^{* * *}$ significance at 0.001 level. }
\end{tabular}

Figure 1 presents the list of AMT and their use frequency. They are grouped into two technologies that save energy, two 3D printing technologies, two industrial robot types and nine digital technologies.

We explicitly show AMT and their frequencies because of a significant gap in the literature as to which technologies are considered AMT as well as their usage. Again, we have to point out that the researched countries are Croatia and Slovenia, lagging far behind Germany and France, and that in our sample on average $64 \%$ of manufactured goods are exported, meaning that a lot of them are suppliers to European or global firms. Only $38 \%$ of firms in our sample produce the end product for consumers, meaning that $62 \%$ of firms are suppliers.

To prove our three hypotheses, we decided to use OLS regression, entering first the control variables, dependent variables and standardized independent variables, and then finally adding the computed moderator variable. Table 4 presents the variables used in OLS regression analyses. 


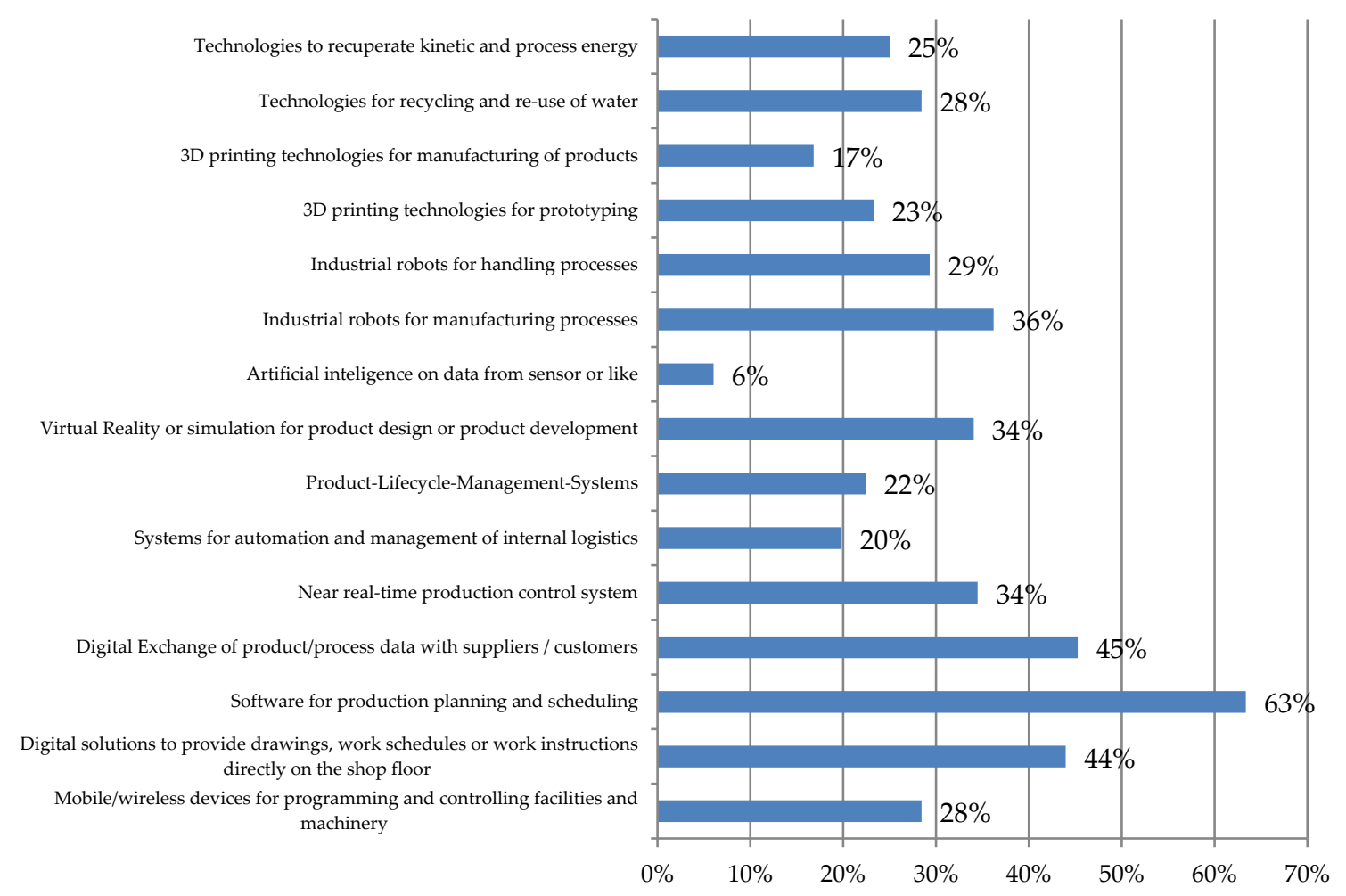

Figure 1. Share of the firms using advanced manufacturing technologies (AMT).

Unlike in [22] where technologies are considered as one construct, we display here all included technologies as independent variables. We did however perform all analyses with technology as one factor (and show results similarly), but for comprehensiveness we decided to include all researched technologies as this is a significant contribution to theory, which according to [28] is missing.

We performed two analyses to analyze our hypotheses, one with the dependent variable as ROS (Model 1) and the other with the dependent variable as products with improved environmental impact—green innovation (Model 2). The results are presented in Table 5. We have used a four-step regression analysis. In the first step, we checked by entering control variables whether the control variables have a strong significant influence on ROS (Model 1) and green innovations (Model 2). If the control variables are significant, this means that the control variables are context-dependent factors. In the second regression, independent variables were entered (AMT and innovation, both green and non-green). In the third regression, the moderator variable was considered (innovation is a moderating variable for green innovations). In order to be able to assess the effect of a moderator variable, all variables must be standardized, which has been done using the SPSS software. A moderator variable changes the strength or direction of an effect between two variables. The moderating variable affects the relationship between the independent variable or predictor variable and a dependent variable or criterion variable. The moderator is constructed from standardized values of all variables in the model. Standardization refers to the process of subtracting the mean and dividing by the standard deviation. Centering the variables and standardizing them will both reduce the multi-collinearity. When using different scales, centering variables is not enough $[60,61]$. The moderator tests if technology strengthens or weakens the relationship. 
Table 4. Variables used in OLS regression analyses.

\begin{tabular}{|c|c|c|}
\hline Variable & Definition & Type \\
\hline Firm size & $\begin{array}{l}\text { Number of employees; the variable is one if the firm has up } 50 \\
\text { employees, two if the firm employs from } 51 \text { to } 250 \text { people, and three if } \\
\text { the firm employs more than } 250 \text { people. }\end{array}$ & Ordinal \\
\hline Product complexity & $\begin{array}{l}\text { Degree of complexity; the variable is one if the firm manufactures } \\
\text { simple parts, two if the product has medium complexity, and three if } \\
\text { the manufacture involves complex products. }\end{array}$ & Ordinal \\
\hline ISO 14000 adopted & The variable is one if the firm has adopted the ISO 14000 certificate. & Dummy \\
\hline Innovation & $\begin{array}{l}\text { The variable is one if the firm has introduced a new product within } \\
\text { the last } 3 \text { years. }\end{array}$ & Dummy \\
\hline Green innovation & $\begin{array}{l}\text { The variable is one if the firm has introduced a new product within } \\
\text { the last } 3 \text { years that also leads to an improved environmental impact. }\end{array}$ & Dummy \\
\hline Year & Year of firm establishment & Metric \\
\hline $\begin{array}{l}\text { Mobile/wireless } \\
\text { devices }\end{array}$ & $\begin{array}{l}\text { The variable is one if the firm uses mobile/wireless devices for } \\
\text { programming and controlling facilities and machinery. }\end{array}$ & Dummy \\
\hline Digital solutions & $\begin{array}{l}\text { The variable is one if the firm uses digital solutions to provide } \\
\text { drawings, work schedules or work instructions directly on the shop } \\
\text { floor. }\end{array}$ & Dummy \\
\hline ERP & $\begin{array}{l}\text { The variable is one if the firm uses software for production planning } \\
\text { and scheduling. }\end{array}$ & Dummy \\
\hline $\begin{array}{l}\text { Digital exchange } \\
\text { of data }\end{array}$ & $\begin{array}{l}\text { The variable is one if the firm uses digital exchange of product/process } \\
\text { data with suppliers/customers. }\end{array}$ & Dummy \\
\hline $\begin{array}{l}\text { Production control } \\
\text { system }\end{array}$ & $\begin{array}{l}\text { The variable is one if the firm uses a near real-time production control } \\
\text { system. }\end{array}$ & Dummy \\
\hline Internal logistics & $\begin{array}{l}\text { The variable is one if the firm uses systems for automation and } \\
\text { management of internal logistics. }\end{array}$ & Dummy \\
\hline PLM & $\begin{array}{l}\text { The variable is one if the firm uses product lifecycle } \\
\text { management systems. }\end{array}$ & Dummy \\
\hline VR/simulation & $\begin{array}{l}\text { The variable is one if the firm uses virtual reality or simulation for } \\
\text { product design or product development. }\end{array}$ & Dummy \\
\hline $\mathrm{AI}$ & $\begin{array}{l}\text { The variable is one if the firm uses artificial intelligence on data from a } \\
\text { sensor or similar. }\end{array}$ & Dummy \\
\hline $\begin{array}{l}\text { IR for manufacturing } \\
\text { processes }\end{array}$ & $\begin{array}{l}\text { The variable is one if the firm uses industrial robots for } \\
\text { manufacturing processes. }\end{array}$ & Dummy \\
\hline $\begin{array}{l}\text { IR for handling } \\
\text { processes }\end{array}$ & $\begin{array}{l}\text { The variable is one if the firm uses industrial robots for } \\
\text { handling processes. }\end{array}$ & Dummy \\
\hline 3D for prototyping & $\begin{array}{l}\text { The variable is one if the firm uses } 3 \mathrm{D} \text { printing technologies } \\
\text { for prototyping. }\end{array}$ & Dummy \\
\hline 3D for manufacturing & $\begin{array}{l}\text { The variable is one if the firm uses 3D printing technologies for } \\
\text { manufacturing of products. }\end{array}$ & Dummy \\
\hline $\begin{array}{l}\text { Recycling and re-use } \\
\text { of water }\end{array}$ & $\begin{array}{l}\text { The variable is one if the firm uses technologies for recycling and } \\
\text { re-use of water. }\end{array}$ & Dummy \\
\hline Energy recuperation & $\begin{array}{c}\text { The variable is one if the firm uses technologies to recuperate kinetic } \\
\text { and process energy. }\end{array}$ & Dummy \\
\hline
\end{tabular}


Table 5. Results of two OLS regressions.

\begin{tabular}{|c|c|c|c|c|c|c|}
\hline & \multicolumn{3}{|c|}{ ROS } & \multicolumn{3}{|c|}{ Green Innovations } \\
\hline & Beta & Sig. & VIF & Beta & Sig. & VIF \\
\hline \multicolumn{7}{|l|}{ Control variables } \\
\hline NACE & 0.085 & 0.268 & 1.311 & 0.054 & 0.433 & 1.304 \\
\hline Firm size & -0.04 & 0.621 & 1.443 & -0.009 & 0.899 & 1.443 \\
\hline Product complexity & 0.02 & 0.79 & 1.231 & 0.032 & 0.639 & 1.24 \\
\hline ISO 14000 & 0.091 & 0.195 & 1.003 & -0.051 & 0.390 & 1.001 \\
\hline Innovation & 0.277 & 0.001 & 1.452 & 0.428 & 0.000 & 1.177 \\
\hline Green innovation & -0.119 & 0.149 & 1.517 & & & \\
\hline Year of firm establishment & 0.145 & 0.08 & 1.521 & 0.119 & 0.049 & 1.065 \\
\hline \multicolumn{7}{|l|}{ Independent variables (AMT) } \\
\hline Mobile/wireless devices & 0.145 & 0.08 & 1.521 & -0.065 & 0.383 & 1.518 \\
\hline Digital solutions & -0.005 & 0.959 & 1.82 & 0.101 & 0.214 & 1.801 \\
\hline ERP & -0.071 & 0.401 & 1.59 & -0.034 & 0.652 & 1.585 \\
\hline Digital exchange of data & 0.039 & 0.621 & 1.381 & -0.012 & 0.862 & 1.377 \\
\hline Production control system & 0.187 & 0.026 & 1.558 & -0.084 & 0.264 & 1.547 \\
\hline Internal logistics & -0.112 & 0.163 & 1.436 & -0.049 & 0.497 & 1.432 \\
\hline PLM & 0.109 & 0.216 & 1.729 & 0.152 & 0.050 & 1.696 \\
\hline VR/simulation & 0.07 & 0.417 & 1.656 & -0.022 & 0.782 & 1.659 \\
\hline AI & 0.243 & 0.001 & 1.273 & 0.089 & 0.192 & 1.261 \\
\hline IR for manufacturing processes & 0.063 & 0.403 & 1.287 & 0.051 & 0.46 & 1.286 \\
\hline IR for handling processes & -0.034 & 0.666 & 1.397 & 0.098 & 0.169 & 1.381 \\
\hline 3D for prototyping & -0.086 & 0.349 & 1.899 & -0.084 & 0.314 & 1.891 \\
\hline 3D for manufacturing & 0.004 & 0.964 & 1.726 & 0.078 & 0.326 & 1.718 \\
\hline Recycling and re-use of water & -0.069 & 0.381 & 1.393 & 0.045 & 0.53 & 1.386 \\
\hline Energy recuperation & -0.023 & 0.765 & 1.378 & 0.102 & 0.148 & 1.357 \\
\hline \multicolumn{7}{|l|}{ Moderating variable } \\
\hline Moderator (ZTECH_X_ZInn) & 0.061 & 0.544 & 2.254 & 0.535 & 0.000 & 1.653 \\
\hline \multicolumn{7}{|l|}{ Change of moderating variable } \\
\hline$\Delta \mathrm{R}$ & 0.002 & 0.544 & & 0.173 & 0.000 & \\
\hline Max VIF & & & 2.254 & & & 1.891 \\
\hline $\mathrm{R}$ & & & 0.452 & & & 0.582 \\
\hline R Square & & & 0.205 & & & 0.339 \\
\hline Standardized R Square & & & 0.111 & & & 0.265 \\
\hline Sig. & & & 0.003 & & & 0.000 \\
\hline
\end{tabular}

ZTECH is short for the standardized value (centered and normalized) of the construct of AMT, therefore the abbreviation TECH, and ZInn is the standardized variable of innovation. By multiplying these standardized values, we obtain the moderating variable for our two regression models. For clarity, the moderator in the first column is entered only once, but there are different values and significances under each model. Finally, in the last step, the effect of the moderating variable is evaluated. If $\Delta R$ is 
significant, it means that the moderating variable is significant, and in other words, the relationship between the independent and dependent variables is indirect rather than direct.

As seen from Table 3 (correlation table), innovations have a significant impact on both ROS and green innovations. However, looking down Table 5 where the moderator factor is displayed, only the first hypothesis is confirmed since the effect of the moderator variable of innovation on the link between technologies and green innovations is significant only for green innovations. This means that innovations are a moderating factor for green innovations, but not for ROS.

This also means that hypothesis H1, "AMT positively relate to the introduction of new green innovation, moderated by innovation", is confirmed (the moderator is significant, but that means that AMT enhance green innovation only indirectly through innovation). Hypothesis H3, "AMT will positively relate to ROS, moderated by innovation", is not confirmed.

Hypothesis H2, "Adoption of the ISO 14000 certificate positively influences green innovations", is also not confirmed, completely in disagreement with the recent literature by Cainelli et al. [28] and García-Quevedo et al. [29]. We can see in Table 5, third row that ISO 14000 certificate adoption does not enhance ROS (which is understandable because those certifications imply cost), but it is not significant even for green innovation. This means that the ISO 14000 certificate is not a predictor of green innovations, but surprisingly the age of the firm is. It means that younger firms already design products that are environmentally friendly.

Doing the same OLS regressions with technologies as the latent variable produces significant results in both cases, meaning that technology does indeed significantly contribute directly to ROS and green innovations. However, we explicitly put all the variables in the model to show which technologies contribute the most to ROS and green innovation. For ROS, technologies such as a near real-time production control system (Standardized Beta $=0.187$ ) and artificial intelligence on data from a sensor or similar (Standardized Beta $=0.243$ ) significantly enhance ROS. For green innovations, as expected, product lifecycle management systems (Standardized Beta $=0.152$ ) contribute the most.

\section{Discussion}

Since our regression shows that green innovations do not directly affect financial performance (ROS), there are other reasons why they are being introduced. The literature argues that the reason why green innovations are launched is for improving brand image. Therefore, our results are in line with Wong [7] in that green innovation has an impact on firms' competitive advantage through their image, and not necessarily through financial gains. This means that green innovations do contribute to the positive image of a firm. Since our first model (with ROS as a dependent variable) is significant and positive, it means technologies and innovation do have a strong positive impact on the financial results of the firm and thus the competitive advantage, but not green innovations. Our results are not in line with Chan et al. [8] and Lin et al. [9], who show that green innovation has a positive effect on firm performance. Rather, we showed that innovations do indeed enhance firm performance but not green innovations. Our findings are in line with Tang et al. [10], who showed that process innovation (AMT) leads to higher performance while green innovation does not $\mathrm{Xie}$ et al. [11] also find the relationship inconclusive. Our results are in line with El-Kassar and Singh [12], who do not find a positive effect of green innovations on performance. They find a positive effect of green process innovations on firm performance, which however is not evident in our data, that is, we find only two technologies (near real-time production control system and artificial intelligence) that enhance firm performance measured through ROS. Przychodzen and Przychodzen [13] and Grewatsch and Kleindienst [14] show mixed results, and therefore we contribute to the literature by showing that technology does in fact contribute to green innovations and even have a moderating effect.

Our findings are in line with Ghobakhloo and Azar [22] in that AMT have a significant positive effect on innovation. We also contribute to theory here by explicitly showing technologies that have been to date only vaguely described by Kusiak [26]. 
Our final results confirm research by Łaszkiewicz [32], who states that firms eco-innovate for corporate image, but with a huge balance between costs and benefits, unlike research by Arranz et al. [33] and Colombelli et al. [34], who state that firms will enter into green innovations only if the government subsidizes them or imposes restrictions.

Our final conclusion and the summary of the discrepancies in the research results actually show that AMT have a positive effect on ROS and enable innovation. By calculating a significant regression coefficient for AMT with respect to ROS, we can conclude that process innovations (if we consider the AMT as a process enabler) also contribute to ROS. However, the complete lack of impact of green innovation on ROS, and the indirect impact of AMT on green innovation could mean that there is still a large research gap in the literature regarding the actual impact of green innovation on the overall position of the firm. It is known from the literature that green innovation improves brand image, and this calls for an additional testing of the impact of a firm's image on ROS; however, this would be more suitable for marketing literature.

\section{Conclusions}

In this research, we investigated the impact of technology on ROS and green innovations. Our findings are that AMT contribute to both the firm's performance and green innovation. However, AMT enhance green innovations only indirectly. We even found that technology is a moderator for green innovations. Even if these results seem obvious, they are a big contribution to theory in several ways. Research on AMT is very scarce, and no universal definition currently exists. We contribute to this stream of literature by explicitly naming AMT and their contribution to financial performance and green innovations.

The second contribution is the research on drivers of green innovations. Here, we made a significant discovery contrary to some current literature. While the majority of research emphasizes that firms will not eco-innovate unless they receive subsidies or severe restrictions are imposed on them, we show that out of all innovations, $66 \%$ are eco-innovations. Our analysis also showed that having the ISO 14000 certificate does not contribute to green innovation, but rather the age of the firm does.

Given that green innovations do not significantly affect ROS, we propose that green innovations are more often done for brand image, which in future might augment sales. However, these green innovations are also costly, so managers, on one hand, should do a good cost-benefit analysis before pushing a green new product, but on the other hand, they need them for competitive reasons.

Nevertheless, innovation is extremely important as we showed that it significantly increases ROS and that technology significantly affects this relationship.

This research offers some managerial and practical implications. Our results suggest that the use of specific AMT boosts firm financial and environmental performance. This presents a clear message to managers that AMT show positive effects in different fields of conducting business. The results of our research also send a clear signal that the majority of firms already consider eco-innovation in new product development, especially among younger firms. This puts a serious demand in front of older, larger firms that "being green" is becoming an important competitive criterion, even if eco-innovation does not significantly affect financial performance at the moment.

As always with research, some issues have to be considered when assessing the reliability, significance, and generalities of the findings. Our data are from two countries, including a little above 200 firms. Although the sample is not small, further research will go towards the analysis of a larger sample from more countries with different manufacturing (AMT use) and environmental strategies. A larger sample will also enable more in-depth study of individual AMT and their impact on financial and environmental performance. 
Author Contributions: Conceptualization, J.P. and I.P.; methodology, J.P. and I.P.; validation, J.P. and I.P.; formal analysis, J.P.; investigation, J.P. and I.P.; writing—original draft preparation, J.P. and I.P.; writing—review and editing, J.P. and I.P.; visualization, J.P.; supervision, J.P.; project administration, I.P. All authors have read and agreed to the published version of the manuscript.

Funding: This research was funded by the Slovenian Research Agency (Research Core Funding No. P2-0190).

Conflicts of Interest: The authors declare no conflicts of interest.

\section{References}

1. Abele, E.; Metternich, J.; Tisch, M. Challenges for Future Production/Manufacturing. In Learning Factories; Springer Nature: Cham, Switzerland, 2019; pp. 1-21.

2. Hussain, S.; Jahanzaib, M. Sustainable manufacturing-An overview and a conceptual framework for continuous transformation and competitiveness. Adv. Prod. Eng. Manag. 2018, 13, 237-253. [CrossRef]

3. Cioffi, R.; Travaglioni, M.; Piscitelli, G.; Petrillo, A.; De Felice, F. Artificial intelligence and machine learning applications in smart production: Progress, trends, and directions. Sustainability 2020, 12, 492. [CrossRef]

4. Vachon, S.; Klassen, R.D. Environmental management and manufacturing performance: The role of collaboration in the supply chain. Int. J. Prod. Econ. 2008, 111, 299-315. [CrossRef]

5. Zhu, Q.; Sarkis, J.; Lai, K.H. Green supply chain management implications for "closing the loop". Transport. Res. E-Log. Transport. Rev. 2008, 44, 1-18. [CrossRef]

6. Vukelic, D.; Agarski, B.; Budak, I.; Simunovic, G.; Buchmeister, B.; Jakovljevic, Z.; Tadic, B. Eco-design of fixtures based on life cycle and cost assessment. Int. J. Simul. Model. 2019, 18, 72-85. [CrossRef]

7. Wong, S.K.S. The influence of green product competitiveness on the success of green product innovation: Empirical evidence from the Chinese electrical and electronics industry. Eur. J. Innov. Manag. 2012, 15, 468-490. [CrossRef]

8. Chan, H.K.; Yee, R.W.; Dai, J.; Lim, M.K. The moderating effect of environmental dynamism on green product innovation and performance. Int. J. Prod. Econ. 2016, 181, 384-391. [CrossRef]

9. Lin, R.-J.; Tan, K.-H.; Geng, Y. Market demand, green product innovation, and firm performance: Evidence from Vietnam motorcycle industry. J. Clean. Prod. 2013, 40, 101-107. [CrossRef]

10. Tang, M.; Walsh, G.; Lerner, D.; Fitza, M.A.; Li, Q. Green innovation, managerial concern and firm performance: An empirical study. Bus. Strateg. Environ. 2018, 27, 39-51. [CrossRef]

11. Xie, X.; Huo, J.; Zou, H. Green process innovation, green product innovation, and corporate financial performance: A content analysis method. J. Bus. Res. 2019, 101, 697-706. [CrossRef]

12. El-Kassar, A.N.; Singh, S.K. Green innovation and organizational performance: The influence of big data and the moderating role of management commitment and HR practices. Technol. Forecast. Soc. 2019, 144, 483-498. [CrossRef]

13. Przychodzen, J.; Przychodzen, W. Relationships between eco-innovation and financial performanceevidence from publicly traded companies in Poland and Hungary. J. Clean. Prod. 2014, 90, 253-263. [CrossRef]

14. Grewatsch, S.; Kleindienst, I. When does it pay to be good? Moderators and mediators in the corporate sustainability-corporate financial performance relationship: A critical review. J. Bus. Ethics 2017, 145, 383-416. [CrossRef]

15. Woo, C.; Chung, Y.; Chun, D.; Han, S.; Lee, D. Impact of green innovation on labor productivity and its determinants: An analysis of the Korean manufacturing industry. Bus. Strateg. Environ. 2014, 23, 567-576. [CrossRef]

16. Chang, C.H. The influence of corporate environmental ethics on competitive advantage, the mediation role of green innovation. J. Bus. Ethics. 2011, 104, 361-370. [CrossRef]

17. Dangelico, R.M.; Pujari, D. Mainstreaming green product innovation: Why and how companies integrate environmental sustainability. J. Bus. Ethics. 2010, 95, 471-486. [CrossRef]

18. Chen, Y.S. The driver of green innovation and green image-green core competence. J. Bus Ethics. 2008, 81, 531-543. [CrossRef]

19. Chen, Y.S.; Lai, S.B.; Wen, C.T. The influence of green innovation performance on corporate advantage in Taiwan. J. Bus Ethics. 2008, 67, 331-339. [CrossRef] 
20. Wang, J.F.; Fei, Z.C.; Chang, Q.; Fu, Y.; Li, S.Q. Energy-saving operation of multistage stochastic manufacturing systems based on fuzzy logic. Int. J. Simul. Model. 2019, 18, 138-149. [CrossRef]

21. Guoyou, Q.; Saixing, Z.; Chiming, T.; Haitao, Y.; Hailiang, Z. Stakeholders' influences on corporate green innovation strategy: A case study of manufacturing firms in China. Corp. Soc. Resp. Environ. Manag. 2013, 20,1-14. [CrossRef]

22. Ghobakhloo, M.; Azar, A. Business excellence via advanced manufacturing technology and lean-agile manufacturing. J. Manuf. Techol. Manag. 2018, 29, 2-24. [CrossRef]

23. Tse, Y.K.; Tan, K.H.; Ting, S.L.; Choy, K.L.; Ho, G.T.S.; Chung, S.H. Improving postponement operation in warehouse: An intelligent pick-and-pack decision-support system. Int. J. Prod. Res. 2012, 50, 7181-7197. [CrossRef]

24. Wu, J.; Zhang, W.Y.; Zhang, S.; Liu, Y.N.; Meng, X.H. A matrix-based Bayesian approach for manufacturing resource allocation planning in supply chain management. Int. J. Prod. Res. 2013, 51, 1451-1463. [CrossRef]

25. Fraunhofer ISI. Available online: https://www.isi.fraunhofer.de/en/themen/industrielle-wettbewerbsfaehig keit/fems.html\#tabpanel-367861728 (accessed on 7 February 2020).

26. Kusiak, A. Smart manufacturing. Int. J. Prod. Res. 2018, 56, 508-517. [CrossRef]

27. Mittal, S.; Khan, M.A.; Romero, D.; Wuest, T. Smart manufacturing: Characteristics, technologies and enabling factors. Proc. Inst. Mech. Eng. Part B J. Eng. Manuf. 2019, 233, 1342-1361. [CrossRef]

28. Cainelli, G.; D'Amato, A.; Mazzanti, M. Resource efficient eco-innovations for a circular economy: Evidence from EU firms. Res. Policy. 2020, 49, 103827. [CrossRef]

29. García-Quevedo, J.; Kesidou, E.; Martínez-Ros, E. Driving sectoral sustainability via the diffusion of organizational eco-innovations. Bus. Strateg. Environ. 2019, 29, 1437-1447. [CrossRef]

30. Arranz, N.F.; Arroyabe, C. Fernandez de Arroyabe, J.C. The effect of regional factors in the development of eco-innovations in the firm. Bus. Strateg. Environ. 2019, 28, 1406-1415. [CrossRef]

31. Prokop, V.; Stejskal, J.; Hajek, P.; Kuba, O. Creating eco-innovations for sustainable entrepreneurship and development within european countries. Eur. J. Sustain. Dev. 2019, 8, 183. [CrossRef]

32. Łaszkiewicz, E. Eco-innovations in SMEs. Przedsiębiorczość Zarzadzanie 2019, 20, 119-131.

33. Arranz, N.; Arroyabe, M.F.; Molina-García, A.; de Arroyabe, J.F. Incentives and inhibiting factors of eco-innovation in the Spanish firms. J. Clean. Prod. 2019, 220, 167-176. [CrossRef]

34. Colombelli, A.; Krafft, J.; Quatraro, F. Firms' growth, green gazelles and eco-innovation: Evidence from a sample of European firms. Small Bus. Econ. 2019, 1-18. [CrossRef]

35. Li, Y. Environmental innovation practices and performance: Moderating effect of resource commitment. J. Clean. Prod. 2014, 66, 450-458. [CrossRef]

36. Tariq, A.; Badir, Y.; Chonglerttham, S. Green innovation and performance: Moderation analyses from Thailand. Eur. J. Innov. Manag. 2019, 22, 446-467. [CrossRef]

37. Tariq, A.; Badir, Y.F.; Tariq, W.; Bhutta, U.S. Drivers and consequences of green product and process innovation: A systematic review, conceptual framework, and future outlook. Technol. Soc. 2017, 51, 8-23. [CrossRef]

38. Amores-Salvadó, J.; Martín-De Castro, G.; Navas-López, J.E. Green corporate image: Moderating the connection between environmental product innovation and firm performance. J. Clean. Prod. 2014, 83, 356-365. [CrossRef]

39. Arana-Solares, I.A.; Ortega-Jiménez, C.H.; Alfalla-Luque, R. Contextual factors intervening in the manufacturing strategy and technology management-performance relationship. Int. J. Prod. Econ. 2019, 207, 81-95. [CrossRef]

40. Ojstersek, R.; Acko, B.; Buchmeister, B. Simulation study of a flexible manufacturing system regarding sustainability. Int. J. Simul. Model. 2019, 19, 65-76. [CrossRef]

41. Gagnon, R.J.; Haldar, S. Assessing advanced engineering technologies. Int. J. Technol. Manag. 1997, 14, 439-469. [CrossRef]

42. Kumar, R.; Singh, H.; Chandel, R. Exploring the key success factors of advanced manufacturing technology implementation in Indian manufacturing industry. J. Manuf. Technol. Manag. 2018, 29, 25-40. [CrossRef]

43. ISI. European Manufacturing Survey (EMS). 2015. Available online: http://www.isi.fraunhofer.de/isi-en/i/p rojekte/fems.php (accessed on 7 February 2020).

44. Prester, J.; Buchmeister, B.; Palčič, I. Effects of advanced manufacturing technologies on manufacturing company performance. Stroj. Vestn. J. Mech. E. 2018, 763-771. [CrossRef] 
45. Lerch, C. European Manufacturing Survey EMS. Available online: https://ec.europa.eu/growth/tools-data bases/regional-innovation-monitor/sites/default/files/report/European\%20Manufacturing\%20Survey.pdf (accessed on 7 February 2020).

46. Marques, P.; Cunha, P.F.; Valente, F.; Leitão, A. A methodology for productservice systems development. Procedia CIRP 2013, 7, 371-376. [CrossRef]

47. Dachs, B.; Biege, S.; Borowiecki, M.; Lay, G.; Jäger, A.; Schartinger, D. Servitisation of European manufacturing: Evidence from a large scale database. Serv. Ind. J. 2014, 34, 5-23. [CrossRef]

48. Bikfalvi, A.; Jäger, A.; Lay, G. The incidence and diffusion of teamwork in manufacturing—Evidences from a Pan-European survey. J. Organ. Chang. Manag. 2014, 27, 206-223. [CrossRef]

49. Lay, G.; Kinkel, S.; Jäger, A. Stellhebel für mehr Produktivität: Benchmarking identifiziert Potenziale zur Steigerung der Produktivität; Mitteilungen aus der ISI-Erhebung-Modernisierung der Produktion, ISI Fraunhofer: Karlsruhe, Germany, 2009.

50. Pons, M.; Bikfalvi, A.; Llach Pages, J.; Palčič, I. Exploring the impact of energy efficiency technologies on manufacturing firm performance. J. Clean. Prod. 2013, 52, 134-144. [CrossRef]

51. Palčič, I.; Pons, M.; Bikflavi, A.; Llach Pages, J.; Buchmeister, B. Analysing energy and material saving technologies' adoption and adopters. Stroj. Vestn. J. Mech E. 2013, 59, 409-417. [CrossRef]

52. Dachs, B.; Kinkel, S.; Jäger, A.; Palčič, I. Backshoring of production activities in European manufacturing. J. Purch. Supply Manag. 2019, 25, 100531. [CrossRef]

53. Nunnally, J.C. Psychometric Theory; McGraw-Hill: New York, NY, USA, 1967.

54. Cronbach, L.J. Coefficient alpha and the internal structure of tests. Psychometrika 1951, 16, 297-334. [CrossRef]

55. Sousa, R.; Voss, C.A. Contingency research in operations management practices. J. Oper. Manag. 2008, 26, 697-713. [CrossRef]

56. Yu, A.S.O.; Figueiredo, P.S.; de Souza Nascimento, P.T. Development resource planning: Complexity of product development and the capacity to launch new products. J. Prod. Innov. Manag. 2010, 27, 253-266. [CrossRef]

57. Bahemia, H.; Squire, B. A contingent perspective of open innovation in new product development projects. Int. J. Innov. Manag. 2010, 14, 603-627. [CrossRef]

58. Bahemia, H.; Squire, B. A Conceptual Model of Open Innovation for New Product Development Projects: Towards a Contingency Theory. In Open Innovation Research, Management and Practice; Tidd, J., Ed.; Imperial College: London, Uk, 2014; pp. 129-157.

59. Martinsuo, M.; Poskela, J. Use of evaluation criteria and innovation performance in the front end of innovation. J. Prod. Innov. Manag. 2011, 28, 896-914. [CrossRef]

60. Meulman, J.J.; van der Kooij, A.J.; Duisters, K.L. ROS Regression: Integrating regularization with optimal scaling regression. Stat. Sci. 2019, 34, 361-390. [CrossRef]

61. Sweet, S.A.; Grace-Martin, K.A. Data Analysis with SPSS: A First Course in Applied Statistics; Pearson Education: London, UK, 2012.

(C) 2020 by the authors. Licensee MDPI, Basel, Switzerland. This article is an open access article distributed under the terms and conditions of the Creative Commons Attribution (CC BY) license (http://creativecommons.org/licenses/by/4.0/). 